\title{
An Example of Political Arithmetic: The Evaluation of Spa Therapy at the Georgian Bath Infirmary, 1742-1830
}

\author{
ANNE BORSAY*
}

Between the Restoration of Charles II in 1660 and the death of Queen Anne in 1714, England experienced a "golden age of political arithmetic" in which the work of William Petty and John Graunt, Gregory King and Charles Davenant was greatly admired. The traditional chronology of modern statistics has either ignored this period altogether or dismissed it as a false start and emphasized the significance of developments during the 1820 s and 1830s. Historians have increasingly contested this orthodox position. Writing in 1989, John Brewer argued that the fiscal-military state, expanding within the cultural context created by the Scientific Revolution, gave rise to a demand for quantitative data to understand and control contemporary problems. ${ }^{1}$ More recently, Julian Hoppit has reasserted the revisionist case, insisting that the Georgians were no less statistically inclined than their later Stuart forefathers. ${ }^{2}$ Hoppit's argument followed Davenant in defining political arithmetic as "the art of reasoning by figures, upon things relating to government". ${ }^{3}$ None the less, he also recognized that not all this information was "officially inspired" because "[m]any outside the corridors of power saw counting as an important way of thinking about their world and the possibilities for policy making". ${ }^{4}$ Medical practitioners were one such group. Political arithmetic acknowledged the relevance of their skills to the large and healthy population that was part of its social mercantilist brief. ${ }^{5}$ Therefore, as early as 1676 , William Petty was calculating the economic drain of premature

* Anne Borsay, PhD, Department of History, University of Wales, Lampeter.

I am grateful to the British Academy, the Wellcome Trust, and the Department of History at the University of Wales, Lampeter, for their generous financial support of the research upon which this paper is based. I also thank Dr Steven Cherry and two anonymous referees for their helpful comments.

\footnotetext{
${ }^{1} \mathrm{~J}$ Brewer, The sinews of power: war, money and the English state, 1688-1783, London, Unwin Hyman, 1989, pp. 221-49.

${ }^{2} \mathrm{~J}$ Hoppit, 'Political arithmetic in eighteenthcentury England', Econ. Hist. Rev., 1996, 49: 516-40, pp. 516-19.
}

\footnotetext{
${ }^{3} \mathrm{C}$ Davenant, The political and commercial works of that celebrated writer Charles D'Avenant, ed. C Whitworth, 5 vols, London, 1771, vol. 1, p. 128.

${ }^{4}$ Hoppit, op. cit., note 2 above, p. 528.

${ }^{5}$ After the Restoration, the mercantilist focus on bullion and currency was complemented by an emphasis on industry and employment in the generation of wealth. With this social mercantilism came a new emphasis on population. C Wilson, England's apprenticeship 1603-1763, 2nd ed., London, Longman, 1984, pp. 353-5, 384. See also A A Rusnock, 'The quantification of things human: medicine and political arithmetic in Enlightenment England and France', $\mathrm{PhD}$ thesis, University of Princeton, 1990 , pp. 8-9, 159-65.
} 
death. Assuming "that by the advancement of the art of medicine, a quarter part more may be born and a quarter part fewer die", he estimated that "the King will gain and save 200,000 subjects per annum, which valued at $20 £$ per head ... will make 4 million per annum benefit to the Commonwealth." John Bellers went further in 1714. Not only did he account "[e]very able industrious labourer, that is capable to have children, who so untimely dies, ... [as] two hundred pound loss to the Kingdom", economic activity was also costed with "regularly labouring people" celebrated as the nation's "greatest treasure and strength" and "every man" in employment valued at "two hundred pounds, or more, to ... the Kingdom".

The purpose of this paper is to tease out the statistical implications of the mercantilist agenda within an institutional setting: the General Infirmary at Bath that was established in 1739 to grant "cripples and other indigent strangers" access to the famous waters. ${ }^{8}$ Three main themes are explored. Firstly, the bond between political arithmetic and medicine is identified in the rhetoric of patient recovery and spa water evaluation. Secondly, hospital records are deployed to assess clinical practice in terms of institutional mortality and treatment efficacy. Finally, the exploitation of these routine data in medical research is examined with reference to the competitive market-place in which spa physicians sold their expertise. But we must begin by placing the case study of the General Infirmary within the contexts of medical quantification and the voluntary hospital movement.

\section{II}

The historiography of medical quantification was initially locked into the same trajectory as modern statistics, with maturation located at the beginning of the nineteenth century. R H Shryock, for example, attributed much significance to the Paris hospitals in the aftermath of the French Revolution. "Here, for the first time", he wrote, "was a clear and emphatic realization of the value of medical statistics. Taken in connection with the contemporary recognition of the need of vital statistics in public hygiene, it afforded indubitable evidence that the mathematical spirit - the great germinating influence in all modern sciences-was at last establishing itself in medicine." And with "the introduction of quantitative procedures", the "whole speculative edifice began to crumble", "statistical checks tend[ing] to demolish the heroic treatment of the old systems". 9 This "big bang" theory was scathing of earlier

\footnotetext{
${ }^{6} \mathrm{~W}$ Petty, The Petty papers: some unpublished writings of Sir William Petty, ed. Marquis of Lansdowne, 2 vols, London, Constable, 1927, vol. 2 , p. 176.

${ }^{7} \mathrm{G}$ Clarke (ed.), John Bellers: his life, times and writings, London, Routledge and Kegan Paul, 1987, pp. 179-80, 204.

${ }^{8} \mathrm{~J}$ Wood, A description of Bath 1765, Bath, Kingsmead Reprints, 1969, p. 279. The archive of the General Hospital (now known as the Royal National Hospital for Rheumatic Diseases) is held at the Bath City Record Office. In this article, the following items have been consulted: 1/1 Committee Minute Book, 16 Feb. 1738-30
}

April 1744 (hereafter MB1); 1/3 Committee Minute Book, 31 May 1749-26 Dec. 1754 (hereafter MB2); 1/14 Committee Minute Book, 20 Feb. 1805-26 Sept. 1810 (hereafter MB14); 1/17 Committee Minute Book, 6 Dec. 1826-26 Dec. 1833 (hereafter MB17); 3/1 Admissions Register, 1742-1752; 4/1 Casebook, 1750-1758 (hereafter CB); 7/6 Annual reports, 1742-1830. Spelling, punctuation and dates have been modernized.

${ }^{9} \mathrm{R}$ H Shryock, The development of modern medicine, London, Victor Gollancz, 1948, pp. 136-7. 


\section{The Evaluation of Spa Therapy at the Georgian Bath Infirmary}

attempts at medical quantification, dismissing the work of researchers like the English physician, James Jurin, as "crude and by no means complicated". ${ }^{10}$ But as Andrea Rusnock's reappraisal has shown, Jurin reached new levels of sophistication in the 1720 s with his investigation of smallpox inoculation. As secretary to the Royal Society, Jurin co-ordinated a correspondence network through which he gathered an impressive array of case histories. From these, he constructed morbidity and mortality ratios to establish whether inoculation was effective and whether it was less dangerous than natural smallpox. This application of quantitative reasoning to what was then a highly controversial technique embodied the search for certainty that was the hallmark of political arithmetic. Alert to the economic, political and demographic instabilities of seventeenth-century England, Graunt, Petty and their successors saw in quantification an alternative to traditional authority that put decisions beyond dispute. " Jurin likewise aimed to override the heated medical, religious and nationalistic debates which surrounded inoculation by supplying a factual resolution. The response to his endorsement of inoculation demonstrates how far this was achieved, objections focusing more on his calculations and figures than on the relevance of medical quantification. ${ }^{12}$

Rusnock concluded that as a result of Jurin's effective quantitative arguments for inoculation, "medical arithmetic strongly influenced, and in fact can be considered part of, English political arithmetic in the eighteenth century." 13 The growth of voluntary infirmaries presented a new institutional setting for this practice. The political arithmeticians had long supported hospital provision, Petty advocating infirmaries to encourage "the most able understandings" of disease among physicians ${ }^{14}$ and Bellers placing them within an ambitious system of state health care which also comprised research institutes and Poor Law medical relief in the community. ${ }^{15}$ With the opening of the first charitable infirmary at Westminster in 1720 their pleas were at least partially heeded, for by 1800 the voluntary hospital movement had over thirty members in England and a further five in Scotland. ${ }^{16}$ Funded by casual benefactions and annual subscriptions, and managed by their financial sponsors working in concert with honorary physicians and surgeons, ${ }^{17}$ these institutions articulated the rhetoric of political arithmetic. Firstly, they projected themselves as "a most certain means of increasing the number of people; as well as of saving a multitude of hands, who are often lost for want of timely assistance". Secondly, they

\footnotetext{
${ }^{10}$ Ibid., p. 118.

${ }^{11}$ Rusnock, op. cit., note 5 above, pp. 288-9; A Rusnock (ed.), The correspondence of James Jurin (1684-1750): physician and secretary to the Royal Society, Amsterdam, Rodopi, 1996, pp. 46-7.

${ }_{12}^{12}$ Ibid., pp. 8-9, 16-26; Rusnock, op. cit., note 5 above, pp. 289-90; A A Rusnock, 'The weight of evidence and the burden of authority: case histories, medical statistics and smallpox inoculation', in R Porter (ed.), Medicine in the Enlightenment, Amsterdam, Rodopi, 1995, pp. 290-9, 304-5.

${ }^{13}$ Rusnock, op. cit., note 5 above, p. 165.
}

\footnotetext{
${ }^{14}$ Petty, op. cit., note 6 above, p. 175.

${ }^{15}$ Clarke (ed.), op. cit., note 7 above, pp. $180-4$.

${ }^{16} \mathrm{~J}$ Woodward, To do the sick no harm: $a$ study of the British voluntary hospital system to 1875, London, Routledge and Kegan Paul, 1974, pp. 147-8.

${ }^{17}$ A Borsay, " "Persons of honour and reputation": the voluntary hospital in an age of corruption', Med. Hist., 1991, 35: 281-94, pp. 283-4; R Porter, 'The gift relation', in L Granshaw and $\mathrm{R}$ Porter (eds), The hospital in history, London, Routledge, 1989, pp. 156-7, 161-2.
} 


\section{Anne Borsay}

"furnish[ed] the physicians and surgeons with more experience in one year, than they could have in ten without it", ${ }^{18}$ thereby answering the call for clinical knowledge. But how far was that experience recorded and quantified? In his study of scientific medicine after 1800, W F Bynum has dated "multiple case reporting" from the midand "systematic record keeping" from the late-eighteenth century; prior to 1750 , he says, doctors frequently described "only single instances of disease and therapies, and only 'cures". ${ }^{19}$ Similarly, Susan Lawrence has maintained that the eighteenthcentury London infirmaries were more important for the "display ... of gentlemanly qualities"- "sagacity, disinterestedness, and diligence"-than for "a possibly protoquantitative approach to hospital medicine"; "Publishing ... men", she continued, "used their charitable patients as they did their private ones, as potential stories of individual disorders".$^{20}$ This stance is corroborated by the shortage of statistical evidence available to the Select Committee on Medical Education for the London hospitals; even in 1834, "only a few ... kept good records ... [and] fewer published systematic analyses of their work, with the mortality of each type of case" ${ }^{21}$ In the provinces, however, the early foundations-Winchester (1736), Bristol (1737), Devon and Exeter (1741), Northampton (1743), Worcester (1746) and Liverpool (1749)took Bellers' advice "that each patient be registered in a book, with the daily prescriptions that is made for them, and how they succeed" ${ }^{22}$ Admissions Registers were set up typically listing the names and parishes of patients, together with their ages and ailments, dates of stay, and state at discharge. ${ }^{23}$ This information was then condensed into numerical tables for printed Annual reports. Relaying the utility of medical charity to lay supporters was an important function of these Reports, but they also meant that the ongoing collection and publication of clinical data became an integral part of institutional medicine well before the closing decades of the eighteenth century.

For Ulrich Tröhler, the rise of the hospital with its record keeping procedures encouraged the emergence of two ideal types of doctor: the "pure observationist clinician", committed to the acute observation of patients and the diligent recording of their treatment and progress; and the "arithmetic observationist clinician" who appreciated the additional need for "numerical analysis" if medical records were to yield their "true meaning". As he elaborated:

In therapeutics the arithmetic observationists' test would involve mathematically the formation of sums, the calculation of averages (i.e. arithmetic means), and at highest, that of ratios,

\footnotetext{
18 'A view of the many peculiar advantages of public hospitals', Gent. Mag., 1741, 11: 476-7, p. 476.

${ }^{19} \mathrm{~W}$ F Bynum, Science and the practice of medicine in the nineteenth century, Cambridge University Press, 1994, pp. 42-3.

${ }^{20}$ S C Lawrence, Charitable knowledge: hospital pupils and practitioners in eighteenthcentury London, Cambridge University Press, 1996, p. 242.

${ }^{21} \mathrm{G}$ Rivett, The development of the London hospital system 1823-1982, London, King Edward's Hospital Fund for London, 1986, p. 30.
}

\author{
${ }^{22}$ Clarke (ed.), op. cit., note 7 above, p. 181 . \\ ${ }^{23}$ B C Turner, $A$ history of the Royal \\ Hampshire County Hospital, Chichester, \\ Phillimore, 1986, p. 12; A Berry, 'Patronage, \\ funding and the hospital patient c. 1750-1815: \\ three English regional case studies', DPhil \\ thesis, University of Oxford, 1995, ch.6; J \\ Lane, Worcester Infirmary in the eighteenth \\ century, Occasional Publications no. 6, \\ Worcestershire Historical Society, 1992, pp. 1-2; \\ $\mathrm{G}$ McLoughlin, $A$ short history of the first \\ Liverpool Infirmary 1749-1824, Chichester, \\ Phillimore, 1978, p. 79.
}




\section{The Evaluation of Spa Therapy at the Georgian Bath Infirmary}

(e.g. success-to-failure ratios). In nosology the occurrence of certain symptoms would be expressed as a fraction of the number of cases studied. The arithmetic observationists would rely on the comparison of results numerically expressed with these simple means, if possible in tabular form, as they realized that this was the sole possibility to fulfil, in a succinct form, the condition of including all cases having occurred during a given time.

Tröhler maintained that the pure observationist clinician became more common only after 1760 "when the restricting and unsettling influence of the various systems ceased to hamper the thoughts of physicians"; arithmetic observationism then ensued from the 1770 s, as the shortcomings of simple counting became obvious. ${ }^{24}$

Although Tröhler may have underestimated the extent to which the general run of eighteenth-century doctors engaged in medical arithmetic, the acceleration of quantitative reasoning after 1760 does not preclude the role which Rusnock charted for Jurin. Both were also agreed that the provision of "hard facts" to challenge established authorities was central to the development of medical statistics. But whereas Rusnock stressed the weaknesses of social authority, Tröhler also included scientific authority and emphasized the "personal responsibility ... [of] the investigator"; the proper use of quantitative methods "required ... stringent moral standards both in the conduct of the research and in the interpretation of results." 25 In line with the individualism of the later Georgian period, medical arithmetic obtained a meritocratic orientation.

\section{III}

The General Infirmary at Bath shared the Georgian "culture of quantification"26 rescued for medicine by Rusnock and Tröhler. Therefore, when a 'Plan and Elevation' was produced during 1738 for fund raising purposes, the trustees promised to rehabilitate future patients "from misery to ease, from impotence to strength, and from beggary and want, to a capacity of getting an honest livelihood, and comfortable subsistence". ${ }^{27}$ The Infirmary was equally enthusiastic about enhancing medical expertise; "if the knowledge of the nature and efficacy of these waters could still be rendered more extensive and certain", declared the 'Plan and Elevation', "it would be doing great service to every individual person, who may hereafter ... have occasion for their use". ${ }^{28}$ But this commitment to the evaluation of spa therapy also created a unique institution. Most voluntary hospitals served their local communities and granted benefactors and subscribers the right to sponsor patients. The General Infirmary, however, catered for the poor who "live[d] at a great distance from ... Bath, and ... [could] not bear the expense of going thither"; local residents with the "divers diseases, illnesses, or disorders" which "long experience" showed the medicinal

\footnotetext{
${ }^{24} \mathrm{U}$ Tröhler, 'Quantification in British medicine and surgery $1750-1830$, with special reference to its introduction in therapeutics', $\mathrm{PhD}$ thesis, University of London, 1978, pp. 62-4. See also J C Riley, The eighteenth-century campaign to avoid disease, London, Macmillan, 1987, pp. 4-7, 55.
}

\footnotetext{
${ }^{25}$ Tröhler, op. cit., note 24 above, p. 469

${ }^{26}$ Hoppit, op. cit., note 2 above, p. 534.

${ }^{27}$ MB1, 16 Feb. 1738.

${ }^{28}$ Ibid.
} 


\section{Anne Borsay}

springs relieved were barred on the grounds that the waters were already accessible to them. The dedication to patients from outside the city led to an admissions procedure which replaced lay sponsorship with medical and moral recommendation. In the words of the Infirmary's Act of Incorporation, a statement was to be "drawn up, and attested by some physician or person of skill" in the applicant's neighbourhood before being sent to the Infirmary. Evidence of charitable status was required from the home parish "or other creditable persons". Upon receipt of these testimonies, the honorary physicians and surgeons then decided if spa therapy was appropriate and suitable cases were put on a waiting list, to be summoned when vacancies arose. ${ }^{29}$ There were no out-patients.

The clientele decanted through this procedure received a treatment regime based on humoral principles. Good health consisted of a stable balance between blood, phlegm, yellow and black bile, the proportions of which fluctuated according to age and personality. ${ }^{30}$ Therefore, drinking and bathing in the waters was prescribed as a means of restoring a proper equilibrium. Published patient histories show that balneology was mixed with medicines. Mr West, a servant from the London area, was given one such package. When admitted with "parapligia" in 1758,

he was so very weak that he could not hobble about the ward, without the support of a crutch, and a stick; ... [and] his knees and feet were so feeble that he could not rise off his chair... . After his taking a purge, upon coming into the hospital, the ague [from which he had previously suffered] returned, and he had a severe fit. A vomit, and the bark prevented his having any more fits.... Then he began to drink a pint a day of the water, and to bathe as often as his weakness, and very thin habit of body would permit. During the first month of his being in this course, he could not perceive that he received any sensible benefit. Afterwards he mended very fast, gathered strength daily; exchanged his crutch for a stick, and could rise out of his chair without help. ${ }^{31}$

Major surgery was apparently exceptional at the General Infirmary; the Minute Books up to 1830 contain only one reference to a serious operation: in 1807 the weekly management committee, on being informed that a patient required amputation above the knee, left the matter "to the discretion of the medical faculty". ${ }^{2}$ The decision to appoint a full-time assistant to the hospital apothecary in 1830 suggests that minor surgical intervention was becoming more common; these services were needed, it was said, because of "a more extensive use of auxiliary remedies, [such] as bleeding, cupping, [and] leeches" ${ }^{33}$ None the less, the Infirmary at Bath did not adopt the rigid "anti-phlogistic regimen [of] bleeding, purging, blisters, and a bland diet" that was applied to patients at the nearby Bristol Infirmary from the late

${ }^{29} 12$ Geo. II, An act for establishing and well governing an hospital or infirmary in the city of Bath, London, 1739, pp. 571, 575-6.

${ }^{30} \mathrm{~N}$ D Jewson, 'Medical knowledge and the patronage system in eighteenth-century England', Sociology., 1974, 8: 369-85, pp. 370-3; C Lawrence, Medicine in the making of modern
Britain 1700-1920, London, Routledge, 1994, pp. 11-2.

${ }^{31}$ Cases of persons admitted into the Infirmary at Bath under the care of Doctor Oliver, Bath, 1760 , pp. $40-5$.

${ }^{32}$ MB14, 11 Nov. 1807.

${ }^{33} \mathrm{MB} 17,10$ Feb. 1830. 


\section{The Evaluation of Spa Therapy at the Georgian Bath Infirmary}

eighteenth century. ${ }^{34}$ Holistic in nature, spa therapy was incompatible with the impersonal, localized pathology which was based on individual organs and legitimated the intensification of surgery. ${ }^{35}$

The mission of the General Infirmary to test the efficacy of the Bath waters has led Audrey Heywood to conclude that it accommodated "one of the earliest, if not the first, scientific trials". ${ }^{36}$ Applying twentieth-century terminology to an eighteenthcentury institution falls into the trap of anachronism. Moreover, Heywood's study was confined to patients suffering from cholica pictonum or lead poisoning: a form of paralysis accompanied by gastro-intestinal pain and fever, vomiting and costiveness. Although this condition-also known as the Devonshire Colic and the West Indian Gripes - was of considerable clinical interest, it accounted for under 7 per cent of admissions between 1751 and 1758, and 1760 and $1879 ;^{37}$ and when investigated by the Infirmary's own physicians, it was absorbed into studies of paralysis or palsy. Therefore, the research activities of the General Infirmary must be subjected to a broader interrogation. More specifically, did the printed annual statistics for all patients accurately reflect the raw data from which they were compiled? What do these records reveal of the therapeutic performance of the Infirmary? How were they deployed by medical practitioners to test the spa waters? And to what programme were these doctors working?

\section{IV}

In using hospital records to assess clinical performance caution is essential, not least because, as medical charities reliant upon voluntary contributions, they were keen to represent themselves as curative institutions. Under these circumstances, there may have been a temptation to "cook the books", perhaps by discharging patients on the brink of death or by pumping up the extent to which their health had benefited. ${ }^{38}$ In the case of the General Infirmary, an Admissions Register surviving for 1742 to 1752, which was compiled for internal consumption and contained 1,643 entries, can be set against the patient statistics in the published Annual reports. There are fewer discharges in the Register than in the Annual reports because the last entry is dated 10 May 1752 and so both the final year, and 1751/52, are

\footnotetext{
${ }^{34} \mathrm{M}$ E Fissell, 'The disappearance of the patient's narrative and the invention of hospital medicine', in R French and A Wear (eds), British medicine in an age of reform, London, Routledge, 1991, pp. 103-5.

${ }^{35} \mathrm{C}$ Lawrence, 'Democratic, divine and heroic: the history and historiography of surgery', in C Lawrence (ed.), Medical theory, surgical practice: studies in the history of surgery, London, Routledge, 1992, pp. 20-3.

${ }^{36}$ A Heywood, "A trial of the Bath waters: the treatment of lead poisoning', in R Porter (ed.), The medical history of waters and spas, Medical History, Supplement, No. 10, London, Wellcome
}

Institute for the History of Medicine, 1990, pp. 91, 93.

${ }^{37}$ Ibid., pp. 93, 96.

${ }^{38} \mathrm{~S}$ Cherry, 'The role of a provincial hospital: the Norfolk and Norwich Hospital, 1771-1880', Popul. Stud., 1972, 26: 291-306, pp. 296-7; G B Risse, Hospital life in Enlightenment Scotland: care and teaching at the Royal Infirmary of Edinburgh, Cambridge University Press, 1986, pp. 230-3; E Sigsworth, 'A provincial hospital in the eighteenth and early nineteenth centuries', College of General Practitioners Yorkshire Faculty Journal, June 1966: 24-31, pp. 28, 31; Woodward, op. cit., note 16 above, pp. 140-1. 


\section{Anne Borsay}

Table 1

Bath General Hospital: the state of patients at discharge, 1742-1752

(a) Admissions Register

\begin{tabular}{lrr}
\hline Condition at discharge & \multicolumn{2}{c}{ Patients discharged } \\
& No. & $\%$ \\
\hline Cured & 364 & 22.2 \\
Much better & 340 & 20.7 \\
Better & 364 & 22.2 \\
Little better & 24 & 1.5 \\
No better & 126 & 7.7 \\
Incurable & 137 & 8.3 \\
Dead & 61 & 3.7 \\
Improper & 87 & 5.3 \\
Hectical & 14 & 0.9 \\
At own request & 16 & 1.0 \\
Misbehaviour & 14 & 0.9 \\
Other & 10 & 0.6 \\
Unrecorded & 86 & 5.2 \\
TOTAL & 1,643 & 100.2
\end{tabular}

(b) Annual reports

Condition at discharge

Patients discharged

$1742-1752$

\begin{tabular}{lcc} 
& No. & $\%$ \\
\hline Cured & 424 & 24.4 \\
Great benefit & 793 & 45.6 \\
Better & - & - \\
No better & 22 & 1.3 \\
Incurable & 142 & 8.2 \\
Dead & 77 & 4.4 \\
Improper & 125 & 7.2 \\
Hectical & - & - \\
At own request & 142 & 8.2 \\
Misbehaviour & 11 & 0.6 \\
Eloped & 4 & 0.2 \\
TOTAL & 1,740 & 100.1 \\
\hline
\end{tabular}

incomplete (Table 1). In turn, this explains the higher proportion of patients whom the published statistics log as leaving at their own request: decisions prompted by an outbreak of smallpox in the latter part of $1752 .{ }^{39}$ The Annual reports also recorded

${ }^{39}$ See MB2, 6 May 1752, 20 May 1752,

17 June 1752, 8 Nov. 1752, 22 Nov. 1752. 


\section{The Evaluation of Spa Therapy at the Georgian Bath Infirmary}

a slightly higher death rate. On the other hand, they described patients as "no better" less frequently and applied the label "great benefit" with more liberality than the Register used the classification "much better". Semantic differences may partly underlie this last inconsistency, especially since it practically disappears when patients who improved after treatment are added to those receiving considerable benefit. Generally speaking, however, the divergences between the two sets of figures are small enough to attribute either to clerical error or to the missing Register entries.

But if there are few signs that routine records were massaged in a sustained and systematic way prior to publication, how the physicians, surgeons and governors deliberated over their initial compilation is largely hidden from history. The Infirmary's publicity stressed the sincerity with which treatment outcomes were supposedly determined. Before being presented to the weekly committee, patients were examined by their own physician and by the medical faculty as a whole. Judgements were to be conservative:

In order that the effects of the waters may not be magnified or misrepresented ..., it is a rule with the physicians never to set down any patient as cured, whilst he has any degree of the disorder for which he was admitted remaining; if the slightest degree be left, he is only set down as much better. None are ever discharged as much better, unless their amendment be very considerable. In doubtful cases, it is usual to attribute too little, rather than too much, to the efficacy of the waters. ${ }^{40}$

Heywood took these assurances at face value, deducing from the varying rates of cure that "the doctors showed clinical judgement when assessing the outcome of the treatment of paralyses from different causes." ${ }^{31}$ But such variations are not in themselves evidence of a scientific protocol. Eighteenth-century diagnosis was often uncertain; short-term solutions were relatively unusual, especially with spa therapy; and the categories used to classify patients at discharge- "cured", "relieved", "better", "incurable", "improper"-were imprecise and hence ripe for inconsistent interpretation, regardless of any intention to deceive. Yet whilst these frailties should not be forgotten, dismissing patient records as statistical fodder, good only to feed the mercantilist rhetoric that the Infirmary voiced, is mistaken. No doubt they were produced with a therapeutic image in mind. However, the quantitative ethos of Georgian medicine and its host society created expectations of accuracy which discouraged flagrant abuse. Consequently, the patient records of the General Infirmary are a legitimate tool with which to attempt an evaluation of spa therapy at Bath.

\section{$\mathbf{V}$}

The starting point for this assessment is institutional mortality and treatment efficacy accessed via the Annual reports which are sampled at five-yearly intervals between 1742 and 1830 . Clearly, such incomplete data runs the risk of distorting the

\footnotetext{
${ }^{40}$ Narrative of the efficacy of the Bath waters in various kinds of paralytic disorders, Bath, 1787, pp. vii-ix.
}

${ }^{41}$ Heywood, op. cit., note 36 above, p. 97. 


\section{Anne Borsay}

Table 2

Bath General Hospital: the state of patients at discharge, 1742-1759 and 1760-1830

(a) Annual reports, 1742-1759 (five yearly samples)

\begin{tabular}{lcc}
\hline Condition at discharge & \multicolumn{2}{c}{ Patients discharged } \\
& No. & $\%$ \\
\hline Cured & 191 & 27.7 \\
Great benefit & 243 & 35.3 \\
Better & 37 & 5.4 \\
No better & 17 & 2.5 \\
Incurable & 52 & 7.6 \\
Dead & 31 & 4.5 \\
Improper & 33 & 4.8 \\
Hectical & 3 & 0.4 \\
At own request & 71 & 10.3 \\
Misbehaviour & 9 & 1.3 \\
Eloped & 2 & 0.3 \\
TOTAL & 689 & 100.1 \\
\hline
\end{tabular}

(b) Annual reports, 1760-1830 (five yearly samples)

\begin{tabular}{lcr}
\hline Condition at discharge & \multicolumn{2}{c}{ Patients discharged } \\
& No. & $\%$ \\
\hline Cured & 1,334 & 28.9 \\
Much better & 2,291 & 49.7 \\
Incurable & 258 & 5.6 \\
Improper & 576 & 12.5 \\
Irregular & 49 & 1.1 \\
Dead & 106 & 2.3 \\
TOTAL & 4,614 & 100.1 \\
\hline
\end{tabular}

overall trend, though the relatively consistent pattern over almost a century suggests that this is minimal danger. The mortality levels reported for the General Infirmary discredit McKeown and Brown's thesis that voluntary hospitals were "gateways to death" during the eighteenth century. ${ }^{42}$ Between 1742 and 1759, the quinquennial annual death rate averaged 4.5 per cent (Table 2) and ranged from a high of 6 per cent in $1750 / 51$ to a low of 3 per cent in 1755/56. After 1760 the figures were presented in a more standardized format. Analysis of these later returns up to 1830 indicates that hospital mortality remained low, averaging a mere 2.3 per cent in the sample years and peaking at 5.8 per cent in $1805 / 6$. This experience matches that of

\footnotetext{
${ }^{42} \mathrm{~K}$ F Helleiner, 'The vital revolution reconsidered', Can. J. Econ. Pol. Sci., 1957, 23: 1-9, p. 6. See also T McKeown and R G Brown,
}

\footnotetext{
'Medical evidence related to English population changes in the eighteenth century', Popul. Stud., 1955, 9: 119-41, pp. 124-6.
} 


\section{The Evaluation of Spa Therapy at the Georgian Bath Infirmary}

other provincial infirmaries, where generally under 10 per cent of patients per annum died in residence. At Shrewsbury and Liverpool, for example, where institutions opened in the later 1740 s, mortality only rarely exceeded 7 per cent over the long eighteenth century. ${ }^{43}$ Likewise, Amanda Berry's comparative study of the Bristol, Northampton, and Devon and Exeter Infirmaries revealed mortality rates of between 2 and 11 per cent during three sample decades from 1765 to $1814 .^{44}$ In the absence of robust local statistics or national data disaggregated according to age and sex, these deaths in hospital cannot be related to general demographic trends; nor is this a very meaningful exercise, given that inmates were a distinctive group by virtue of their ill health. ${ }^{45}$ What can be evaluated is the thesis that voluntary infirmaries boosted the population. Even at the turn of the century, there were only an estimated 4,000 hospital beds available country-wide: too few to make a noticeable mark. ${ }^{46} \mathrm{As}$ a result, diet, sanitation, housing and the development of other medical facilities all exerted more influence in the mortality matrix. ${ }^{47}$ Added to these factors is the dominant thrust of fertility in Georgian demography, working through earlier and more frequent marriage. ${ }^{48}$ Therefore, if not the death-traps that their critics alleged, voluntary hospitals contributed little to the demographic expansion trumpeted by their mercantilist rhetoric.

Over and above population preservation, medical care pursued the more effective use of existing labour, infirmaries being welcomed as a means of returning the sick poor to physical fitness and so to employment. Between 1742 and 1759, the Annual reports for the General Infirmary recorded "cures" for 27.2 per cent of patients, the yearly level generally ranging from a fifth to a third. The average for the sample years after 1760 was slightly higher at 28.9 per cent and the variation was also less pronounced with figures rarely dropping below a quarter. Throughout the Georgian period, the anchoring of spa therapy in humoral theory meant that cure was envisaged as reverting to a proper equilibrium rather than the more demanding repair of a defective organ or bodily function. Nevertheless, treatment outcomes at Bath were less propitious than those of sister institutions: the Salop Infirmary, for example, normally reported a minimum cure rate of 50 per cent; while at Liverpool eight out of ten patients were regularly classified in this way, at least until the second decade

\footnotetext{
${ }^{43} \mathrm{H}$ Bevan, Records of the Salop Infirmary from the commencement of the charity to the present time, Shrewsbury, Sandford and Howell, 1847 , 'A comparative average statement of in and out-patients'; McLoughlin, op. cit., note 23 above, pp. 101-3. See also M E Fissell, Patients, power, and the poor in eighteenth-century Bristol, Cambridge University Press, 1991, p. 108; Lane, op. cit., note 23 above, pp. 38-9; Risse, op. cit., note 38 above, pp. 46-9, 289-91; Sigsworth, op. cit., note 38 above, pp. 25-9; Woodward, op. cit., note 16 above, pp. 142, 153-8.

${ }^{44}$ Berry, op. cit., note 23 above, p. 243.
}

\footnotetext{
${ }^{45}$ Sigsworth, op. cit., note 38 above, p. 31.

${ }^{46} \mathrm{~B}$ Abel-Smith, The hospitals, 1800-1948: $a$ study in social administration in England and Wales, London, Heinemann, 1964, p. 1.

${ }^{47} \mathrm{~S}$ Cherry, 'The role of English provincial voluntary general hospitals in the eighteenth and nineteenth centuries', 2 vols, PhD thesis, University of East Anglia, 1976, vol. 2, pp. 270-1.

${ }^{48} \mathrm{P}$ Hudson, The industrial revolution, London, Edward Arnold, 1992, pp. 147-9; E A Wrigley and R S Schofield, The population history of England, 1541-1871: a reconstruction, London, Edward Arnold, 1981, pp. 418-19.
} 
of the nineteenth century. ${ }^{49}$ Only when the "cured" and "great benefit/better/much better" categories are combined does the proportion of patients leaving the General Infirmary with some improvement in their health climb to over 70 per cent.

What were the reasons for this poorer performance? Although the medical and moral recommendations required for admission may have generated more "respectable" patients than the systems of sponsorship by benefactors and subscribers operating elsewhere, any link between clinical efficacy and virtue is not easily substantiated. A more tangible factor is age, usually noted in the Admissions Register and in an extant Casebook containing letters of recommendation for 1,618 patients admitted between 1750 and 1758 . Children and elderly people were under-represented at the General Infirmary, relative to the demography of England as a whole. Less than 10 per cent of patients, but a third of the total population, were under 15 years old, whilst the proportion over 60 years was under half the national average. This age structure was reflected in the mean age: 34.1 years for men listed in the Admissions Register and 28.9 years for women; and 34.0 years for men listed in the Casebook and 30.3 years for women. Yet these age characteristics did not depart significantly from those for other provincial voluntary hospitals. ${ }^{50}$ Where the General Infirmary diverged was in its disease profile.

Before 1760, disease categories were not differentiated in the printed Annual reports, but Table 3 culls this information from the Admissions Register for the decade after 1742, largely retaining the contemporary terminology. In some cases-notably "weakness" and "lameness", the lost use of limbs and numbness - the language was vague. Other categories were less ambiguous. Rheumatism, for example, produced stiff and painful joints and muscles, in ischias focusing on the hip. With paralysis there was a loss of voluntary motion, which with hemiplegia affected one side of the body. The miscellaneous musculo-skeletal disorders were primarily contracted limbs, distorted vertebrae and sciatica, while the diseases of the digestive system were mainly jaundice and cholica pictonum. Under the heading of skin complaints came erysipelas, "scorbutic" or "impetiginous" eruptions, and leprosy-not the serious disfiguring kind but a general term for rough, itchy or discharging pimples. The "other" category contained "hectical" or fever patients, those who left at their own request or eloped, and those expelled for misbehaviour. These classifications from the Admissions Register were rationalized in the relatively standardized disease categories that the Annual report published from 1760 (Table 4). The clinical profile thrown up by these two sources is a chronic one. Almost 70 per cent of patients suffered from rheumatism, paralysis or another musculo-skeletal disability, and a further one-in-ten had leprous conditions. It was this recruitment of patients with long-standing ailments which impaired the therapeutic performance of the General Infirmary.

\footnotetext{
${ }^{49}$ Bevan, op. cit., note 43 above; McLoughlin, op. cit., note 23 above, pp. 101-3. See also Lane, op. cit., note 23 above, p. 41 ; Risse, op. cit., note 38 above, pp. 46-9; Woodward, op. cit., note 16 above, pp. 153-9.
}

\footnotetext{
${ }^{50}$ Berry, op. cit, note 23 above, p. 221 ; M W Dupree, 'Family care and hospital care: the "sick poor" in nineteenth-century Glasgow', Soc. Hist. Med., 1993, 6: 195-211, p. 204; Fissell, op. cit., note 43 above, p. 103, table 5.1; Risse, op. cit., note 38 above, p. 87 .
} 


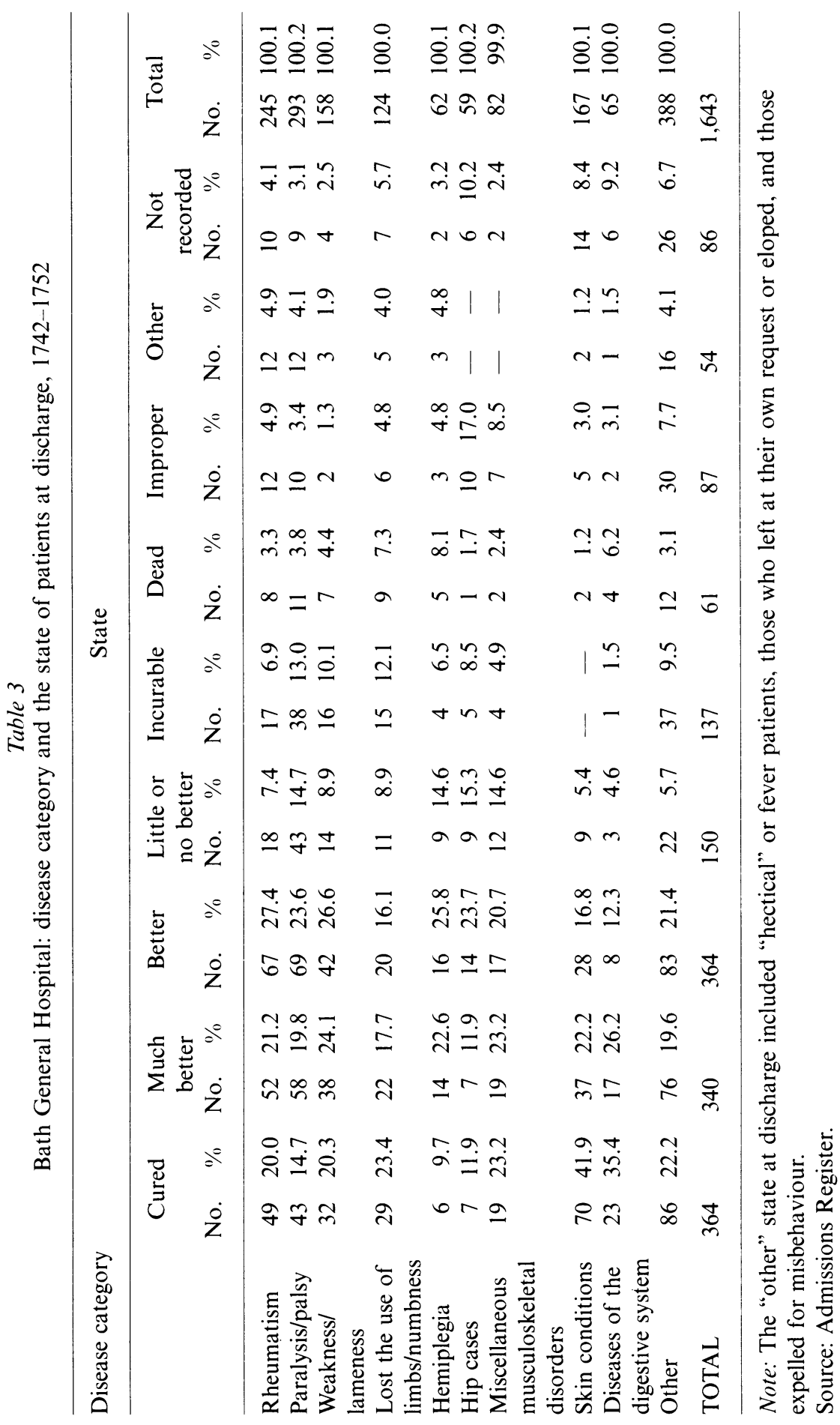




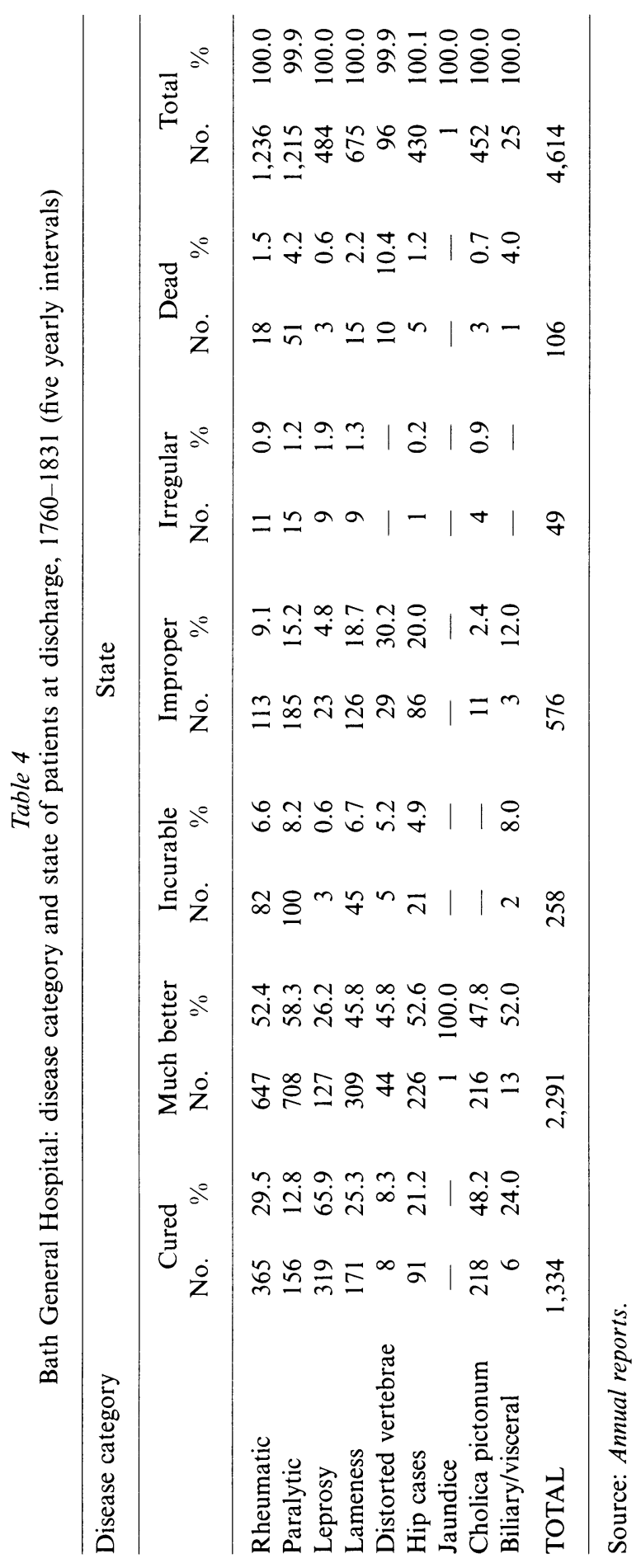




\section{VI}

The statistics prepared for the Annual reports also formed the basis of ad hoc research by physicians conducting evaluations of the spa waters. Confidence in the clinical potential of the Bath springs survived virtually unchallenged for most of the Georgian period. ${ }^{51}$ In the mid-1750s, however, trouble broke out over the composition of the waters when an Irish physician called Charles Lucas refuted the presence of the sulphur to which their curative properties were historically credited. ${ }^{52}$ Clinical value was not repudiated, but it was attributed to "the ability of the water to induce evacuation in the body, and thereby restoration of proper balance of the humours". Instead of the "bitumen, sulphur, nitre, and ... fixed alcali" customarily used by chemists to explain the healing properties, Lucas found only small quantities of iron, marine salt and "a calcarious, or sparry stone". Consequently, "[w]hatever warm water, charged with these like ingredients can do, that, and that alone is to be expected from Bath water". ${ }^{53}$ These arguments were soon to be regurgitated by another physician, William Baylies from Evesham in Worcestershire. But his indictment went further. Whereas Lucas posited only that the physicians of the General Infirmary published inaccurate patient histories to hide the ineffectiveness of their treatments, Baylies proclaimed a wider conspiracy in which both the Bath Corporation and the local medical establishment actively hindered the analysis of the waters, and the Infirmary-as a vehicle for their self-interest-deliberately suppressed clinical evidence. ${ }^{54}$

This "balneological war" had much to do with commercial competition and professional rivalry. ${ }^{55}$ It is no coincidence that Lucas and Baylies were perceived as "outsiders" trying to gate-crash a local market threatened by their criticisms, and that both had practised the apothecary's lowly trade before ascending to the rank of physician. ${ }^{56}$ The General Infirmary was implicated on both scores, restricting honorary posts to established local practitioners ${ }^{57}$ and perpetuating the occupational inferiority of the apothecary by confining him to a paid post. ${ }^{58}$ Against the trend

\footnotetext{
${ }^{51} \mathrm{~J}$ Barrett, 'Spas and seaside resorts, 1660-1780', in J Stevenson, J Barrett, P Corfield and $\mathrm{R}$ O'Day, The rise of the new urban society, Open University Third Level Course, English Urban History 1500-1780, Units 13-16, Milton Keynes, Open University Press, 1977, p. 69; T Fawcett and S Bird, Bath: history and guide, Stroud, Alan Sutton, 1994, p. 65.

${ }^{52} \mathrm{~T}$ Fawcett, 'Selling the Bath waters: medical propaganda at an eighteenth-century spa', Somerset Arch. Nat. Hist., 1990, 134: 193-206, p. 194.

${ }^{53} \mathrm{C}$ Lucas, An essay on waters. In three parts, London, 1756, pp. 320, 323-5. See also C Lucas, Cursory remarks on the methods of investigating the principles and properties of Bath and Bristol waters, Bath, 1764.

${ }^{54} \mathrm{~W}$ Baylies, Practical reflections on the uses and abuses of Bath waters, London, 1757, pp. 122-3, 131-2; W Baylies, An historical account of the rise, progress and management of the General
}

Hospital, or Infirmary, in the city of Bath, Bath, 1758, pp. 126, 128.

${ }^{55} \mathrm{M}$ Neve, 'Natural philosophy, medicine and the culture of science in provincial England: the cases of Bristol 1796-1850 and Bath 1750-1820', $\mathrm{PhD}$ thesis, University of London, 1984, p. 80.

${ }^{56}$ Dictionary of national biography, ed. L Stephen and S Lee, London, Smith, Elder, 1909, vol. 12, pp. 231-4; E A B Barnard, 'An eighteenth-century Worcestershire doctor: William Baylies of Evesham, 1724-87', Trans. Worc. Arch. Soc., 1945, 4: 35-54, pp. 36-8; Neve, op. cit., note 55 above, pp. 80-1, 84-92.

${ }^{57}$ Baylies, Practical reflections, op. cit., note 54 above, pp. 124-30; Baylies, Historical account, op. cit., note 54 above, pp. 49, 62-71, 85-9.

${ }^{58} \mathrm{M}$ Nicolson, 'The metastatic theory of pathogenesis and the professional interests of the eighteenth-century physician', Med. Hist., 1988, 32: 277-300, pp. 285-6; Wood, op. cit., note 8 above, pp. 296-7. 
detected by Rusnock, however, the sulphur controversy did not trigger a quantitative defence. Even before Lucas went into print, the Reverend Dr Robert Leyborne launched a pre-emptive strike by diverting a charity sermon, preached to raise income for the Infirmary, to the praise of its research record. "Already have the physicians of this place been enabled ... to confute some dangerous mistakes of the most experienced in other places ... ; and with unparalleled disinterestedness and benevolence, they engage not to confine what other knowledge they gain ..., but to publish it throughout the world". 59 This was an exaggeration, given the sporadic appearance of clinical material throughout the long eighteenth century. Moreover, though one of the honorary physicians, Rice Charleton, responded quickly to Lucas, he did so in a riposte which propounded a dubious line between "sulphur"-the chemical element-and "sulphureous"-an expedient term that was "applicable to any oily or greasy substance" ${ }^{60}$ A second physician was later just as conservative. No stranger to quantification, William Oliver had sent Jurin accounts of inoculation when working in Plymouth. ${ }^{61}$ But in 1760 his reaction to the tirade from Lucas and Baylies was a collation of fifteen case histories, detailing previous treatment, the patient's condition at admission, and the regimen followed. ${ }^{62}$ Under pressure, the physicians of the General Infirmary sought refuge in traditional medical authority.

In the calmer atmosphere of the early 1750s, however, John Summers had begun a quantitative approach to spa therapy that was to flourish intermittently until the early nineteenth century. Summers used the Admissions Register to challenge the assertion of Dr Richard Mead "that warm bathing is hurtful to all" paralytic patients. His argument was that "the original cause of palsies ... proceed[ed] from obstructions in the nervous system, or the interrupted course of the arterial blood." This was manifest in "an inability in those organs, which are allowed to be the instruments of sensation and motion". Therefore, the muscles were "inactive, soon become cold, flaccid, numb, and often wasted". Summers believed that the experience of the General Infirmary demonstrated the efficacy of the Bath waters for such paralysis. Stressing the "great variety" among the 310 such cases which had been admitted since the Infirmary opened in 1742, he reported that 57 were "cured", 151 were "much better", 45 were "no better", 42 were "incurable" and 12 had died. Another three continued in residence. Age was not an impediment to treatment. Of the "more than two thirds" for whom some improvement was recorded, "above thirty were more than 40 years old, fifteen of whom were turn'd of 50, and five were 60 and upwards". Even hemiplegia-the "most obstinate" palsy which frequently frustrated "the most skilful practitioners"-responded to therapy with four "cures" and a further 27 of the 43 patients receiving "benefit". ${ }^{63}$ Paralytic cases were likewise the focus of a Narrative of the efficacy of the Bath waters, produced under the auspices

\footnotetext{
${ }^{59} \mathrm{R}$ Leyborne, Charity conducive to God's glory: a sermon for the benefit of the General Hospital in Bath, Bath, 1754, p. 32.

${ }^{60}$ Fawcett, op. cit., note 52 above, p. 201. 296.

${ }^{61}$ Rusnock, op. cit., note 12 above, pp. 294 ,

${ }^{62}$ Cases, op. cit., note 31 above; B Boyce, The benevolent man: a life of Ralph Allen of Bath,
} 


\section{The Evaluation of Spa Therapy at the Georgian Bath Infirmary}

of the honorary physicians and surgeons in 1787. Most of the volume was devoted to a selection of 52 patient histories and there was no attempt to define the aetiology of their condition. What is interesting was the incorporation in the preface of a statistical summary based on Register entries from 1776 to 1785. In all, 833 of the 1,102 patients admitted with paralytic conditions "benefited" from water therapy and only 269 did not. Moreover, success rates were quoted for several varieties of this disorder, including "shaking palsies, which have been formerly observed not to receive equal benefit from the use of the Bath". ${ }^{64}$

The simple enumeration adopted by Summers and the Narrative was extended by Rice Charleton and William Falconer who used the patient records of the General Infirmary for more refined exercises in statistical probability; in other words, they were fully fledged representatives of Tröhler's "arithmetic observationist clinicians". ${ }^{65}$ In the 1770s, Charleton published Three tracts on Bath water which, like the later Narrative, bridged the old medical world and the new. The first tract was a chemical analysis of the spa and the third was a reproduction of William Oliver's case histories, but in the second was a more innovative statistical investigation, again concentrating on paralysis. Whereas Summers blamed the nervous system or the blood supply for paralytic disorders, Charleton judged them to be "seat[ed] in the brain". If more nuanced, his depiction of the syndrome embodied similar elements.

The symptoms of the palsy are, sometimes, a total deprivation of the operations of the mind and internal senses; sometimes only a slight abatement of them. It affects either the whole body from the head downwards, except the heart and muscles of respiration, or one side only, or a particular limb. The parts affected are deprived of sensation alone, or of motion alone, or of both; they either swell and are bloated, or waste and decay; they are either too cold, or preternaturally hot.

Charleton broke new ground, however, in framing his project as an hypothesis, the aim being to discover whether the waters were "useful or detrimental in palsies". Distinguishing eight main types of palsy, he tabulated the fate of patients admitted between 1751 and 1764 and deemed "proper" for a "trial of the waters". His conclusion was that they were helped because 813 benefited and only 113 were "no better". More specific questions were also posed and answered with sophistication. For instance, the common assumption that warm bathing aggravated apoplectic strokes was tested and rejected after a comparison of mortality ratios: the hemiplegic category was slightly less likely to die than the patient body as a whole, despite containing a number of smallpox fatalities. ${ }^{66}$

This arithmetic analysis of spa therapy was pushed further by William Falconer. Falconer conducted a number of studies, but one of his most elaborate was an examination of rheumatic cases, published in 1795. Whereas Georgian medicine construed palsy as a bodily malfunctioning, Falconer believed that rheumatism was

\footnotetext{
${ }^{64}$ Narrative, op. cit., note 40 above, pp. $\mathrm{x}-\mathrm{xiii}$.

${ }^{65}$ Tröhler, op. cit., note 24 above, pp. 62-4.

${ }^{66} \mathrm{R}$ Charleton, Three tracts on the Bath waters, 2nd ed., Bath, 1774, vol. 2, 'An enquiry
}

into the efficacy of Bath water in palsies', pp. 3, 8-9, 12-14, 93-5. See also Summers, op. cit., note 63 above, pp. 17-19; Narrative, op. cit., note 40 above, pp. xiii-xiv. 


\section{Anne Borsay}

Table 5

Bath General Hospital: the state of patients at discharge, 1785-1793 and 1775-1779

\begin{tabular}{lcc}
\hline State & \multicolumn{2}{c}{ Ratio } \\
\hline & $\begin{array}{c}1 \text { May } 1785 \text { to } \\
19 \text { November } 1793\end{array}$ & $\begin{array}{c}1 \text { January } 1775 \text { to } \\
31 \text { December } 1779\end{array}$ \\
\hline The number of persons Cured, is to the whole, & 1 to 2.7532 & 1 to 2.8189 \\
as & 1 to 2.5389 & 1 to 2.4861 \\
Those Much Better, as & 1 to 6.5231 & 1 to 8.5238 \\
Those Better, as & 1 to 11.158 & 1 to 8.7317 \\
1 to 1.0984 & 1 to 1.1438 \\
Those No Better, as & 10.158 to 1 & 6.9556 to 1 \\
The number Benefited is to the whole, as & & \\
The number Benefited is to them who received &
\end{tabular}

Source: W Falconer, An account of the use, application and success of the Bath waters in rheumatic cases, Bath, 1795, pp. 64-5.

caused by external cold and aggravated by a damp environment. ${ }^{67}$ The muscles, especially those "in the neighbourhood of the joints", were attacked; there were visible "marks of inflammation, particularly swelling"; the affected parts were "sore and tender to the touch"; and the pain-even when "dull and obtuse" rather than "acute and lancinating"- was "very fatiguing and troublesome" and "diminished considerably the strength of the body in general". In fact, where the attacks were violent and frequent, "the extremities [were] reduced into a state nearly resembling that of a palsy, being nearly deprived of strength, pale, emaciated, and cold" ${ }^{68}$ Falconer based his investigation of this debilitating complaint on rheumatic patients admitted to the General Infirmary between 1785 and 1793. They were divided into five groups, according to their state at discharge: 154 were "cured", 167 were "much better", 65 were "better", 53 were "no better" and five had died. Two of the five deaths had been due to other causes, one smallpox and the other an intestinal disorder. Thirteen of those "no better" were "[d]eemed improper for the use of the waters, as being hectical, having ulcers, or what rendered confinement in an hospital improper"; three discharged themselves against professional advice; and two eloped. These cases Falconer struck out on the grounds that treatment was incomplete. In the remaining sample of 424 , he saw "a full and decisive testimony of the advantage to be reaped from ... the [spa] in rheumatic cases". But to ensure that his chronological sample was not "particularly favourable", "relative proportions" or ratios were calculated to compare the results with an earlier sequence (Table 5). From this operation, he concluded that the "two periods" did not "materially differ": that those discharged as "cured" and "much better"-_"the two most important articles"-were

\footnotetext{
${ }^{67} \mathrm{~W}$ Falconer, An account of the use, application and success of the Bath waters in rheumatic cases, Bath, 1795, pp. 17, 20.
}

${ }^{68}$ Ibid., pp. 1, 3, 8-10. 


\section{The Evaluation of Spa Therapy at the Georgian Bath Infirmary}

"nearly on a level". A similar methodology was applied to the clinical careers of patients. For example, it was deduced that since the proportion of males to females was 1.9041 to 1.0 , rheumatic conditions were not more common among women. Furthermore, by adjusting for the sex ratio, and projecting a success rate for men from the rate achieved by women, he was able to suggest that male patients responded more effectively to treatment. ${ }^{69}$

The research of Charleton and Falconer shows that in the later eighteenth century the General Infirmary was playing host to clinicians who were deploying techniques of statistical probability as well as basic numerical skills. By this stage, quantification had become "an accepted method for identifying certain features of individuals and societies"; indeed, pioneering physicians of social medicine-John Haygarth in Chester, Thomas Percival in Manchester-were developing a concept of public health through their statistical comparisons of urban and rural mortality. ${ }^{70}$ At Bath, however, there were no heirs to arithmetic observationist clinicians. The reasons are complex. Charleton's motivations are especially elusive because he received a conventional medical education at Oxford. Falconer, on the other hand, trained at the Edinburgh medical school where he was a contemporary of Haygarth and Percival. Popular with Dissenters barred from Oxbridge, Edinburgh teaching conveyed medicine as a means for progressive social reform, and from the 1780 s emphasized the connection between epidemic disease and the "atmospheric economy". ${ }^{71}$ Falconer's medical arithmetic was a product of this pedagogic experience. In general, however, Edinburgh-trained physicians with an interest in quantification-often of radical political and religious beliefs-were predisposed to locate in urban and industrial areas, whilst elite physicians in elegant spa towns were not attracted by the meritocratic ethos of later Georgian medical arithmetic. Furthermore, the rise of localized pathology was starting to marginalize holistic balneology within mainstream medicine. The eclipse of quantification at Bath is comprehensible in these terms. As Rusnock acknowledged, the personal narrative remained persuasive because of its capacity "to invoke a range of human sentiments that numerical odds $d[i d]$ not". ${ }^{72}$ Consequently, it made sense for physicians peddling an old-fashioned treatment to revert to traditional discourses and justify spa therapy with reference to the case history ${ }^{73}$ or even the "mysterious causes" of its clinical impact. ${ }^{74}$

\section{VII}

The physicians of the General Infirmary who evaluated the spa were fervent proponents of clinical empiricism. "Theory", wrote Summers, "but seldom coincides with practice, and rather misguides and leads us to error, than assists us in investigating 292.

${ }^{69}$ Ibid., pp. $50-67$.

${ }^{70}$ Rusnock, op. cit., note 5 -above, pp. $208-10$,

${ }^{71}$ Tröhler, op. cit., note 24 above, pp. 182, 185-6, 450, 458. See also M Ignatieff, $A$ just measure of pain: the penitentiary in the industrial revolution 1750-1850, Harmondsworth, Penguin Books, 1978, pp. 60-8.

\footnotetext{
${ }^{72}$ Rusnock, op. cit., note 12 above, p. 306.

${ }^{73} \mathrm{E}$ Barlow, An essay on the medicinal efficacy and employment of the Bath waters, Bath, 1822.

${ }^{74} \mathrm{G}$ Smith Gibbes, $A$ second treatise on the Bath waters, Bath, 1803, p. 9.
} 


\section{Anne Borsay}

the true cause, or fixing on the proper method of curing diseases". ${ }^{75}$ Charleton too was scathing of speculative medical systems which "when well founded, have proved of little use in the art of healing; and when ill founded, an eternal hindrance to our progress in it"; "the credit of the Bath waters", he averred, was "irrefragably ... support[ed]" by the "facts". ${ }^{76}$ The Narrative endorsed this view, stating that its intention was to relate "[f]acts alone ... [because] it is from these only, when described with candour, that the ... properties of any remedy can be ascertained". ${ }^{77}$ And in condemning "uncertain or false theory", Falconer likewise emphasized the importance of "practical knowledge". ${ }^{78}$ His study of rheumatic cases was "little more than a plain statement of facts" derived from "personal observation" and none of these facts were "related on the authority of the writer, to which he himself ha[d] not been an eye-witness" ${ }^{79}$ The repository of facts with which to pursue the empiricist ideal was the Infirmary's Admissions Register: a document which provided "a testimony to be relied on, and such a proof as none can dispute" ${ }^{80}$

Despite the professions of objectivity, contrasting the spa evaluations with the statistics which they borrowed suggests that this was not the criterion which informed the accumulation of medical knowledge. John Summers' findings for paralytic patients admitted between 1742 and 1751 can be set against the Admissions Register which runs from 1742 to 1752 (Table 3). This first Register from which Summers drew his sample listed only 293 and not 310 paralytic cases. The number of "cures" was also lower at 43 and not 57. Furthermore, whereas Summers pronounced that 151 patients were "much better", the Register revealed 58 in this state with an additional 69 who were "better". When these two categories are merged, the total is still only $127 .{ }^{81}$ Therefore, even if the other discrepancies are blamed on accidental error, it is difficult to avoid the conclusion that classifications were being deliberately conflated to present spa therapy in a kindly light. Since the last year of the Admissions Register is 1752 , later research cannot be juxtaposed with the raw statistics. As we have seen, however, clinical conditions were disaggregated in the Annual reports after 1760. Neither their typology of treatment outcomes nor the Infirmary's administrative year exactly coincided with the dates and categories picked by Falconer, Charleton and the Narrative. But if the figures are converted into percentages, a comparison is feasible. With Falconer's study of rheumatic cases, there was no hyperbole about the rate of cure. On the contrary, his figure of 36.3 per cent for the years 1785 to 1793 was slightly lower than the "official” statistic of 39.1 per cent. Rice Charleton's data seem to have been similarly concurrent: just over three-quarters of all paralytic patients were either "cured" or "benefited" from the Bath waters between 1751 and 1764,82 according to the Annual reports for the five years to 1764 , the proportion was the same. However, by combining patients who were "cured" with those who merely "benefited", Charleton cannily hid the size of the group which did not fully return to health. Moreover, the Narrative arouses suspicion of tampering. Of the

\footnotetext{
${ }^{75}$ Summers, op. cit., note 63 above, p. 8.

${ }^{76}$ Charleton, op. cit., note 66 above, p. 14.

${ }^{77}$ Narrative, op. cit., note 40 above, p. vii.

${ }^{78} \mathrm{~W}$ Falconer, An essay on Bath waters, London, 1770, pp. 19-20.
}

\footnotetext{
${ }^{79}$ Falconer, op. cit., note 67 above, pp. vi-vii.

${ }^{80}$ Summers, op. cit., note 63 above, p. 4 .

${ }^{81}$ Ibid., p. 4

${ }^{82}$ Charleton, op. cit., note 66 above,
} pp. 12-14. 
paralytic cases which it catalogued for 1776 to $1785,21.5$ per cent were "cured" and 41.2 per cent were "much better". ${ }^{83}$ Yet, during this decade, the Annual reports described only 12.6 per cent of patients as "cured" and 54.7 per cent as "much better". It would appear that the "much better" category was being raided for cures.

The adoption of an interpretative framework which inflated the therapeutic image of the spa was consistent with the commercial environment of medical practitioners whose incomes were dependent upon the prosperous constituencies who patronized Bath. Heywood recognized this dimension when she argued that local doctors set up their clinical trial of the waters in the hope that it would attract wealthy patients with gout. If this was so, they were disappointed since few poor patients were admitted with the condition. ${ }^{84}$ However, the concentration on research into paralytic and rheumatic diseases was inspired by the medical market-place. Physicians explained this preoccupation with reference to the intransigence of paralysis and rheumatism, and the effectiveness of the spa in their treatment. The Casebook for 1750 to 1758 bears out that "cure [was] ... uncertain and difficult", ${ }^{85}$ for patients had run the gauntlet of medical care, consulting both unorthodox and regular practitioners before turning to Bath. Thomas Phillips, a middle-aged man from Southampton, was "troubled with a nervous weakness which appears to threaten a palsy" and had "spent the greatest part of his substance upon quacks to no purpose". ${ }^{86}$ Abraham Jaquet, "a poor lad" in his mid-teens, who had "lost the use of his legs and thighs" and could not "retain his waters", found "no benefit" from the "many things" prescribed by his apothecary at Andover. ${ }^{87}$ And Anne Cane with "a paralytic disorder from the vertebra of the loins downwards" had been resident in the Devon and Exeter Hospital from which she was discharged after making no progress. ${ }^{88}$

This last patient was not alone in having been treated at another infirmary. One in ten Casebook letters mentioned contact with medical institutions and in 68 cases there was a direct referral. But if the General Infirmary was a last resort, did palsy best succumb to the spa? The Narrative was adamant that it did, claiming "paralytic cases ... [to be] the principal, but by no means the only instances, wherein the efficacy of the Bath waters is manifested in the Bath hospital". ${ }^{89}$ Falconer agreed and after publishing his Practical dissertation on the medicinal effects of the Bath waters in 1790 , he directed his research towards rheumatism on the grounds that the value of the spa for palsies was already incontrovertible. ${ }^{90}$ However, the Admissions Register discloses that neither paralysis nor rheumatism delivered the highest levels of recorded cure; rather, this distinction fell to the generic skin complaint of leprosy and to disorders of the digestive system (including cholica pictonum) (Table 3). The data compiled in the standardized format adopted by Annual reports after 1760

\footnotetext{
${ }^{83}$ Narrative, op. cit., note 40 above, pp. $\mathrm{x}-\mathrm{xi}$.

${ }^{84}$ Heywood, op. cit., note 36 above, p. 89.

${ }^{85}$ Summers, op. cit., note 63 above, pp. 17-19.

See also Charleton, op. cit., note 66 above, pp.

8-9; Narrative, op. cit., note 40 above, pp.

xiii-xiv.
}

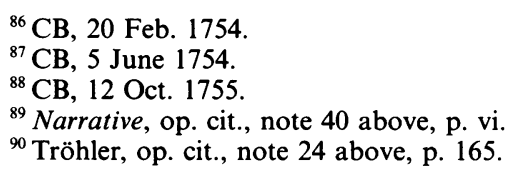


repeated this pattern (Table 4), with leprosy and cholica pictonum-now identified as separate diseases-capping the hierarchy of cures.

The neglect of leprosy in the research activities of physicians to the General Infirmary undercuts their contention that clinical investigations prioritized complaints for which the spa waters were especially suitable. The position with regard to paralysis is more complicated. Palsy was among the symptoms of cholica pictonum-hence its assimilation into the analysis of paralytic patients. Both Rice Charleton and the Narrative broke down their data into different types of palsy. ${ }^{91}$ Charleton distinguished "palsies from mineral effluvia" and "palsies from cyder and bilious cholics". The first category was only small, accounting for 40 cases or 4 per cent of the sample. The second category, however, comprised 237 cases or almost a quarter of the sample and was not far behind the most numerous palsy, hemiplegia, with 283 cases. The Narrative throws up a similar picture. Twenty-one patients or 2 per cent of the sample were the victims of "palsy from lead or copper"; 264 patients-again virtually a quarter-had "palsy from colic". But of most significance was the success rate in these groups, cures or improvements in health being recorded in at least 90 per cent of cases. In contrast, the overall rates were lower, Charleton's study producing a figure of 77.2 per cent and the Narrative 75.6 per cent. With the omission of cholica pictonum, these rates dropped again to 71.8 per cent and 67.8 per cent respectively. ${ }^{92}$ The absorption of cholica pictonum thus enhanced the therapeutic profile for the paralytic disorders as a whole. Furthermore, the isolation of complete cures, which only the Narrative allows, shows that whereas just one-in-five of all paralytic patients was said to have fully recovered, the ratios were between four and five in ten for "palsy from colic" and "palsy from lead and copper". Removing cholica pictonum lowered the residual ratio to one in $7.5 .^{93}$ Consequently, Charleton's decision to integrate cure and benefit masked the extent to which most palsies resisted total remedy. ${ }^{94}$

A common cause of cholica pictonum among patients of the General Infirmary was exposure to lead in the course of employment-perhaps as a painter or plumber, glazier or silver worker. ${ }^{95}$ Alternatively, they were poisoned by cider contaminated

\footnotetext{
${ }^{91}$ Charleton, op. cit., note 66 above, pp. 12-5; Narrative, op. cit., note 40 above, pp. $\mathrm{x}-\mathrm{xi}$.

${ }^{92}$ Thirty-eight of Charleton's 40 "palsies from mineral effluvia" (95 per cent) responded to treatment and 218 of his 237 "palsies from cyder and bilious cholics" (92 per cent). When these cases are extracted, the sample falls from 1,053 to 776 cases, 557 of which were recorded as "cured and benefited" (71.8 per cent). Nineteen of the Narrative's 21 patients with "palsy from lead and copper" (90.5 per cent) were said to have improved and 260 of the 264 with "palsy from colic" ( 98.5 per cent). When these cases are excluded, the sample contracts from 1,102 to 817 cases, 554 of which were registered as "cured", "much better" or "better" (67.8 per cent).
}

\footnotetext{
${ }^{93}$ Ten of the 21 cases of "palsy from lead and copper" and 117 of the 264 cases of "palsy from colic" were "cured". When these figures are subtracted from the 237 "cures" registered for the 1,102 cases as a whole, 817 patients generated only 110 "cures".

${ }_{94}$ See also Heywood, op. cit., note 36 above, p. 97.

${ }^{95}$ The General Infirmary did not request details of employment, but this information was volunteered in about 15 per cent of cases. The tally was as follows: pauper 49 , soldier 40 , labourer 35 , servant or coachman 15 , painter 12 , mariner or seaman 11 , plumber 7 , shoemaker 7 , husbandman 6 , carpenter 5 , glazier 4 , weaver or woolcomber 4 , gardener 3 , potter 3 , barber 2 , mason 2, lead or silver worker 2 , shepherd 2 , other 35 .
} 


\section{The Evaluation of Spa Therapy at the Georgian Bath Infirmary}

with lead during manufacture. ${ }^{96}$ The average stay for all patients was protracted, the Admissions Register and the Casebook recording means of 149.5 and 133.7 days respectively-longer than the 43 days for contemporaries at the nearby Bristol Infirmary or even the 105 days at Northampton. ${ }^{97}$ With such lengthy removal from the extrinsic sources of lead, the prospect of a cure was good, aided by an adequate diet and by a regime of immersion in spa waters which may have encouraged the expulsion of noxious substances. ${ }^{98}$ But for the affluent visitors and residents who came to Bath lead was an unlikely cause of palsy; their conditions were largely of organic origin and more intractable. Like cholica pictonum, leprosy-used in the hospital records as a blanket term for skin complaints-was likewise particularly associated with the lower orders, being aggravated by unwholesome food, poor hygiene and damp or poorly ventilated environments. Rheumatism, conversely, struck across the social spectrum; indeed, Falconer argued that "the lower ranks" were more vulnerable than "the higher ranks of mankind"- not due to poverty or harmful employment but to rashly exposing themselves to extremes of hot and cold. But though two-thirds of the General Infirmary's rheumatic cases were held to be culpable, ${ }^{99}$ their therapeutic responses were worth displaying in the public gaze because paying patients were also victims. The research schedule of the Infirmary-with its neglect of leprosy and its emphasis on paralysis and rheumatism-reflected this social economy of disease. In other words, the physicians geared their enquiries to the trade in medicine, aiming to invest the waters with a scientific credibility in areas which appealed to their fee-paying clientele.

\section{VIII}

This paper has examined the rhetoric and the reality of political arithmetic at Bath's General Infirmary during the long eighteenth century. Publicity which the Infirmary issued espoused the mercantilist goal of a healthy population achieved through the advance of clinical knowledge. The extent to which this rhetoric was realized has been assessed with reference to the practice of medical quantification: a phenomenon which emerged at the end of the seventeenth century from the concern of political arithmetic with disease and mortality. The routine statistics published by the General Infirmary were a reliable representation of its internal records. They demonstrate that although the institution was not a den of mortality, it did report cure and relief for a smaller proportion of patients than hospitals whose populations suffered from acute rather than chronic ailments. The physicians who periodically tapped into this resource for research purposes were selective, overlooking conditions which did not serve their economic interests and overstating the clinical effects of the waters by merging categories of outcome. Yet though this programme was insufficiently sustained and rigorous to equate with a modern

\footnotetext{
${ }^{96} \mathrm{H}$ A Waldron, 'The Devonshire colic', Med. Hist., 1969, 13: 74-81, p. 74.

${ }^{97}$ Berry, op. cit., note 23 above, p. 238.
}

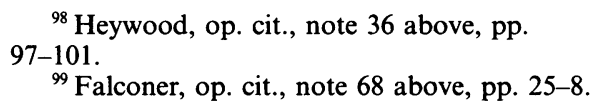




\section{Anne Borsay}

clinical trial, scientific knowledge inevitably breaches the mythical paradigm of objectivity. Therefore, the practice of medical quantification at the General Infirmary qualifies as an example of political arithmetic and so testifies to the vitality of eighteenth-century statistics in the voluntary as well as the statutory sector. 